\title{
Е.П. Бережная
}

Новосибирский государственный педагогический университет

\section{Статья Ю.Н. Тынянова \\ «О композиции «Евгения Онегина»: к вопросу о метаинтерпретации}

Морфологическая школа, принесшая в изучение литературы категории «лингвистического модернизма» 1920-х годов, осуществила на деле две общетеоретические задачи: 1) создала автономную область литературной науки, противопоставляемую разным фактам культуры, и 2) разграничила литературные тексты в отдельные концепты, сводимые друг с другом на уровне стиля. (Ср. из ст. Эйхенбаума Б.М. Вокруг вопроса о формалистах (1924 г.): «...Наука о литературе, поскольку она не является только частью истории культуры, должна быть наукой самостоятельной и специфической, имеющей свою область конкретных проблем... Превращение исторического параллелизма разных рядов культуры (“"их соответствий”) в функциональную (причинно-следственную) связь насильственно и потому не приводит к плодотворным результатам. Делаемый при этом выбор одного ряда, как порождающего собой остальные, диктуется не научными, а миросозерцательными потребностями и вносит в науку тенденциозную предпосылку. Явления упрощаются, схематизуются, теряют именно то, что отличает их от других явлений» [Эйхенбаум, 1976, с. 17]). Следствием подобного имманентного подхода к искусству явился мощный качественный поворот, выявляемый как в перспективе собственно художественного ряда, так и существующий за его пределами. Этот поворот, ознаменовавший, своего рода, смену парадигмы, глубоко засвидетельствован теоретическими и историко-литературными работами Тынянова 20-х годов.

Пафос открытия, присущий научным поискам Тынянова, в совершенно особом смысле выразился в пушкиноведческих трудах ученого. Поэтика Тынянова содержала принципиально новый взгляд на морфологическое изучение словесного искусства. Оформляющим центром тыняновских идей являлось представление о литературном тексте как модели горизонтального среза смыслообразовательных структур. В главной теоретической книге «Проблема стихотворного языка», а также в статье «О композиции «Евгения Онегина», тесно связанной с проблематикой книги, эта опора на «деформирующийся» в стиховой конструкции смысл слова обнаруживается в наибольшей степени. Исходя из спецификаторской трактовки словесного искусства Тынянов не столько исследует смысловую природу литературного произведения, сколько учитывает те изменения и «деформации», которые приводят к порождению смысла произведения литературы. В научном наследии Тынянова онегинистика представляется в качестве «деформирующего инструмента», определившего перспективы тыняновской литературной теории.

«Согласно морфологической концепции, Тынянов не претендовал на семантическую интерпретацию "Онегина", но без его анализа ряда композиционных блоков было бы впоследствии крайне затруднительно восприятие смыслопоро- 
ждающей природы романной структуры. Тынянов увидел в “Онегине” множество смыслообразующих формантов, которые послужили в дальнейшем опорой для оригинальных интерпретаций» [Чумаков, 1999, с. 234]. Предлагаемый тезис Ю.Н. Чумакова выступает в качестве основного кода, регулирующего определенные установки данной работы.

Неоконченная статья «О композиции “Евгения Онегина”» занимает совершенно особое место среди пушкинских работ Тынянова. Богатая теоретической проблематикой статья Тынянова впервые полностью была опубликована в 1975 г. (сб.: Памятники культуры. Новые открытия), когда имманентный анализ структуры пушкинского романа в стихах уже утвердился в работах Ю.Н. Чумакова, Ю.М. Лотмана и С.Г. Бочарова [Чумаков, 1970; Лотман, 1966; Лотман, 1975; Бочаров, 1967]. В неисторическом плане мы можем говорить о самостоятельной ценности этой статьи, поскольку зафиксированная в ней тыняновская теория пушкинского романа (не движение событий, но движение словесных масс) продолжает воздействовать на толкования онегинского текста, существующие в альтернативных парадигмах. Вместе с тем в корпусе работ Тынянова, освещающих онегинскую проблематику, статья «О композиции “Евгения Онегина”» продемонстрировала одно из положений теории литературной эволюции об ограниченности «авторского намерения» художественным материалом, иначе говоря, о неизбежном разрыве между замыслом и воплощением ${ }^{1}$. В связи с вышесказанным рассмотрим в конспективном изложении процесс творческого оформления статьи автором, которое также представляется необходимым компонентом в тыняновской теории о смыслообразующих структурах литературного текста.

Первоначально Тыняновым была задумана статья под названием «Ленский». Замысел статьи о Ленском переплетался у Тынянова с построением генеральной схемы литературной борьбы 1810-1820-х годов, изложенной им в монографии «Архаисты и Пушкин». На материале Ленского Тынянов сформулировал теорию «свободного героя» пушкинского романа, который не только нес в себе «перемен ный психологический» и «физический» материал, но в конечном итоге становился «эквивалентом единства» для развертывания этого материала. Возможно, что последовавшую за «Архаистами...» статью «Ленский» Тынянов собирался посвятить вопросу о героях в «Евгении Онегине» ${ }^{2}$. В шестом наброске «Ленского» Тынянов сформулировал эту тему следующим образом: «На вопросе о “герое” яснее всего сказывается деформирующая сила художественного произведения - и необычайная податливость деформируемого материала» [Тынянов, 1977, с. 417]. В предшествовавших пяти вариантах статьи предварительно рассматривались общетеоретические вопросы, связанные с проблемами поэтического языка, жанра, героя и т.п. Но при всем том статью предполагалось посвятить именно Ленскому ${ }^{3}$. Особо следует отметить шестой вариант статьи, «... продвинувшийся далее всех прочих». Как было сказано выше, в шестом наброске статьи «Ленский» (представ-

${ }^{1}$ Ср. из ст. Ю.Н. Тынянова «О литературной эволюции»: «...Авторское намерение может быть только ферментом. Орудуя специфическим литературным материалом, автор отходит, починяясь ему, от своего намерения. Так, "Горе от ума" должно было быть «"высоким" и даже "великолепным" (по авторской терминологии, не сходной с нашей), но получилось политической “архаистической” памфлетной комедией. Так, “Евгений Онегин” должен был быть сначала “сатирической поэмой”, в которой автор “захлебывается желчью”. А работая над 4-й главой, Пушкин уже пишет: “Где у меня сатира? О ней и помину нет в «Евгении Онегине»”» [Тынянов, 1977, с. 278].

${ }^{2}$ Комментаторы к сб.: Поэтика. История литературы. Кино (1977) не учитывают статьи «Архаисты и Пушкин» при изложении тыняновской теории «героя» пушкинского романа.

${ }^{3}$ См. комментарии А.П. Чудакова [Тынянов, 1977, с. 415]. 
ленном в наиболее полном виде) Тынянов приступил к проблеме «героя» в «Евгении Онегине», обозначив несколько фундаментальных формул для постижения структуры персонажа пушкинского романа: герой как «устойчивая движущаяся точка», как «мотивировка литературных явлений» или «единица словесной динамики произведения» [Тынянов, 1977, с. 417, 419]. Однако дальнейшего развития эта тема не получила, растворившись в решении теоретических проблем, связанных со структурой пушкинского романа в целом. На этом этапе работы была «... осуществлена коренная переработка» статьи «Ленский», и в беловом варианте, седьмом по общему счету, появилось новое заглавие «О композиции "Евгения Онегина"». ${ }^{1}$ Персонаж в «Композиции...» рассматривался лишь в качестве частного случая общей проблемы конструкции пушкинского романа в стихах.

Приведенный нами конспект первоначальных вариантов тыняновской статьи «О композиции...» показывает, прежде всего, «отход» Тынянова в общетеоретические построения, в результате которого стала терять свою референтность локальная тема о Ленском. Сам интерес Тынянова к конкретным фактам литературной жизни, конечно, остается и подтверждение этому - теоретические и историколитературные работы исследователя, пронизанные утверждаемым значением «случайных» и поверхностных структур в литературе. Между тем методологический принцип Тынянова таков, что для него соотнесенность с широкомасштабными перспективами, с интенцией на результаты, которые еще скажутся в будущем - на первом плане. (См., например, у Л.Я. Гинзбург: «Тынянов знал цену мелким мыслям, но заведомо мелких фактов для него не существовало. Он считал, что факт надо подержать в руках и посмотреть, не приведет ли он к чему-нибудь крупному...». «Он всегда искал факт, который пружинит и подымает большое обобщение...». «Стилистическая деталь, конкретный факт литературной и общественной жизни, в процессе исследования растут, разветвляются, дорастают до исторического обобщения, до теоретической формулы» [Гинзбург, 1983, с. 164, $162,163]$.

Подводя некоторый итог рассуждениям о теме Ленского, перспективно было бы иметь в виду идентичность творческого оформления статьи «О композиции...» (включая первоначальные наброски о Ленском) с утверждаемой Тыняновым поэтикой «Евгения Онегина». В построении научной статьи мы наблюдаем определенные механизмы, которые порождают структурные характеристики пушкинского романа в стихах. Так, например, любое исследование Тынянова содержит в себе импульс энергосодержащей незавершенности текста. В поэтике «Евгения Онегина», разрабатываемой Тыняновым, универсальным выражением жанровой структуры «Онегина» является принцип развертывания «свободного романа» в «бесконечность», основанный на конструирующей роли читателя в создании произведения. Не менее важное значение в смыслообразовании пушкинского романа имеет введенное Тыняновым (и не поддержанное другими формалистами) понятие эквивалентности текста, реализуемое в апперцептивном поле читателя. На семантическом уровне эти «эквиваленты текста» могут быть «додуманы» и наполнены любым содержанием в зависимости от установки воспринимающего. Го-

\footnotetext{
${ }^{1}$ Тынянов вернулся к «проблеме Ленского» в статье «Пушкин и Кюхельбекер», впервые опубликованной в 1934 г., но поиски портретных черт прототипа привели его в конечном итоге к теоретической неудаче. Ср.: «В чертах героя, в главном сюжетном пункте, катастрофе-дуэли - можно проследить конкретные черты... Сюжетная катастрофа - дуэль, как известно, вызвала упреки современной критики в немотивированности... Таким образом, характеристика Ленского: “Дух пылкий и довольно странный”, - и его обидчивость в начале III главы оказались недостаточно сильными мотивировками внезапной дуэли. Повидимому, ее мотивировали портретные черты прототипа, оставшиеся вне поэмы» [Тынянов, 1968 , с. 285].
} 
воря о научном сочинении Тынянова (в частности, о статье «О композиции “Евгения Онегина”»), мы отметим одно из отличительных его свойств, как, например, намеренное усложнение и «затемнение» смысла собственной речи, что, в свою очередь, усиливает к нему внимание воспринимающего «субъекта». Все сказанное выше позволяет сделать вывод о том, что научные тексты Тынянова создавались по законам литературной формы, а в основе художественного творчества, соответственно, лежали теоретические романы. (Ср. из письма Тынянова Шкловскому 31 марта 1929 г.: «...Я смотрю на свои романы, как на опыты научной фантазии, и только. Я думаю, что беллетристика на историческом матерьяле теперь скоро вся пройдет, и будет беллетристика на теории» [Воспоминания о Тынянове, 1983 , с. 28]).

Текст «О композиции “Евгения Онегина"» датируется 1921-1922 г., и в плане статьи, состоящем из трех разделов, помимо «вопроса о героях» и «структуры «Евгения Онегина», первостепенное место занимают так называемые «общие предпосылки» ${ }^{1}$. Насколько важны для Тынянова были эти общие предпосылки, свидетельствует перечень формулировок, отражающий различные уровни анализа стихотворного языка: симультанность практической речи и сукцессивность поэтической, семантические ряды и стиховой ряд, отличие поэтического языка от практической речи и отличие от прозы. Все названные проблемы в области теории стиха были решены Тыняновым в написанной в 1923 г. книге «Проблема стихотворного языка» (опубликована в 1924 г.). Темой статьи о «Евгении Онегине» стал вопрос о художественной структуре пушкинского романа, интерпретированный как «...применение “общих предпосылок” к анализу одного произведения» [Тынянов, 1977, с. 416]. Общность замыслов статьи «О композиции...» и будущей «Проблемы стихотворного языка» не подлежит сомнению. Однако для результативного осмысления темы нашей работы необходимо помнить о том, что статья о «Евгении Онегине» создавалась раньше, чем теоретически была осмыслена проблематика стихового языка. В дальнейшем Тынянов сосредоточился именно на «общих предпосылках». Статья «О композиции “Евгения Онегина”» осталась незаконченной.

Завершая характеристику творческого осмысления Тыняновым статьи «О композиции...», мы апеллируем к двум следующим тезисам.

1. Научный текст Тынянова (в частности, статья о «Евгении Онегине» с многочисленными отброшенными вариантами) представляет собой одну из форм выражения литературного сочинения и, соответственно, требует перестройки референтных уровней построения текста.

2. Пушкинский роман в стихах явился «резервуаром» теоретической энергии Тынянова. В статье «О композиции “Евгения Онегина”» обозначился поворот Тынянова в сторону теоретической проблематики, связанной с выявлением смыслообразующих компонентов литературного текста.

Рассмотрим несколько подробнее некоторые композиционные блоки пушкинского романа, описанные Тыняновым в статье «О композиции...», как генерирующие «...восприятие смыслопорождающей природы романной структуры» [Чумаков, 1999, с. 234].

Следует отметить, что уже в первой «онегинской» работе «Архаисты и Пушкин» Тыняновым были прогнозированы особенности художественной структуры «Евгения Онегина», обнаруживающие стиховую форму пушкинского романа в стихах: установка на словесную динамику произведения и, соответственно, на бессюжетность; энигматичность и противоречивость «героя», являющиеся следствием «сложных эмоциональных колебаний стиха» и, наконец, персонификация

${ }^{1}$ См. комментарии А.П. Чудакова [Тынянов, 1977, с. 416]. 
«литературных отступлений», которые функционируют как «эквиваленты единства» героя. В «Архаистах...» Тынянов коснулся вопроса о различии между прозой и поэзией, конструируемом на противопоставлении архаистической и карамзинистской теорий слова: с одной стороны, эмоционально-убедительное поэтическое слово «высокой оды» с установкой на имманентное звучание, с другой, логически-ясное слово «легкой поэзии», где важную роль играет «принцип семантической точности». Проблема соотношения стиха и прозы, волновавшая Тынянова в период написания «Архаистов и Пушкина», находила свой адресный источник в теоретизирующих опытах Кюхельбекера, в его жанровом новаторстве.

Рассуждения Кюхельбекера имели важное значение в теоретических построениях Тынянова. Отметим один из случаев использования Тыняновым критического замечания Кюхельбекера, который писал о восьмой главе «Евгения Онегина» следующее: «Из лучших строф 35-я, свидетельствующая, что Ал. Пушкин племянник В. Пушкина, великого любителя имен собственных: особенно мил Фонтенель с своими «твореньями» в этой шутовской шутке» ${ }^{1}$. В «Проблеме стихотворного языка» Тынянов напишет о значении имен собственных в становлении лексического строя произведения, а также в усилении «стиховой абстрактности» слова: «...Наиболее сильными по лексической окраске будут слова без основного признака... Сюда... относятся... собственные имена, очень сильно сохраняющие лексическую окраску... Ими дается как бы лексическая тональность произведения» [Тынянов, 1993, с. 90]. Далее, за примерами пересчета имен у карамзинистов (прием, перешедший к ним от французских поэтов), Тынянов цитирует обсуждаемую Кюхельбекером XXXV строфу «Евгения Онегина» как представительствующую в поэтике именного перечня:

Прочел он Гиббона, Руссо,

Манзони, Гердера, Шамфора

Madame de Stael, Биша, Тиссо

[Там же, с. 91].

Подобный пересчет имен у Пушкина давал не только лексическую тональность произведения. Имена собственные, введенные в стиховую конструкцию, были всего лишь «названиями», не имеющими предметного адресата. (См. у Пушкина: «Женское имя (в стихах) так же мало реально, как все эти Хлои, Лидии или Делии XVIII века. Это только названия» [Тынянов, 1968, с. 130]). Все такого рода перечисления подчеркивали различие между стихотворным языком и прозаическим, их взаимную неэквивалентность друг другу. Эта нетождественность двух уровней художественной речи выразилась у формалистов в представлении о поэтическом языке как языке, обращенном на себя, теряющем коммуникативную устремленность и иллюзию правдоподобия.

С сопоставления поэзии и прозы начинается статья Тынянова «О композиции “Евгения Онегина”». В «Архаистах и Пушкине» была постулирована мысль Тынянова о том, что в основе художественного творчества лежит динамический принцип создания произведения. Согласно этому принципу, любой элемент литературной системы должен рассматриваться лишь в относительной замкнутости своих значений. (Ср. из «Проблемы стихотворного языка»: «Единство произведения не есть замкнутая симметрическая целость, а развертывающаяся динамическая целостность; между ее элементами нет статического знака равенства и сложения, но всегда есть динамический знак соотносительности и интеграции» [Тынянов, 1993, с. 26]). Поэтому пушкинский роман в стихах - это «свободный ро-

\footnotetext{
${ }^{1}$ См.: [Немзер, 1990, с. 40-51].
} 
ман», раздвигающий границы жанра и стремящийся в конечной точке своего определения стать «не-жанром») ${ }^{1}$.

Идея динамизации была важна для Тынянова устранением статического признака в определении композиции. (Ср. запись от 9 июля 1922 г. в дневнике Эйхенбаума о беседе с Тыняновым: «Сегодня говорили о термине “композиция”. Термин изжитой. Он предлагает - “динамика", чтобы избегнуть статического элемента» [Тынянов, 1977, с. 509]). Кроме того, замена термина «композиция (в данном контексте) литературного произведения» «динамикой» содержала в себе своеобразный «перевод» конкретного и устойчивого понятийного выражения на затрудненную в экспликации терминологию, поддающуюся разным интерпретациям. Статья о «Евгении Онегине» написана в тот период, когда в научных занятиях Тынянова стала доминировать тенденция к разработке «...понятийного, терминологического аппарата, который позволил бы теоретически четко осмыслять наблюдаемые историко-литературные факты» [Там же, с. 506].

Мысль о том, что формалисты стремились к разработке «понятийного, терминологического аппарата» в ущерб анализу историко-литературных фактов общепризнанна и расценивается как выражение специфики культурно-исторической ситуации 1910-1920-х годов. В 1926 г. Б.М. Эйхенбаум в статье «Теория “формального метода"» выразил общеопоязовский взгляд на эволюцию формализма как на «...дальнейшее дифференцирование теоретических и историко-литературных понятий» [Эйхенбаум, 1987, с. 407]. Тынянов, прежде обращения к конкретному анализу элементов художественного текста, выстраивает иерархический ареал понятий, осмыслением которых пронизана почти каждая его историко-литературная работа. В самой теоретической книге «Проблема стихотворного языка» эта опора на обоснование понятий обнаруживается в наибольшей степени.

Следует отметить, что термины Тынянова содержат в себе высокую степень метафоричности и, своего рода, барочные сдвиги как результат напряжения различных методологических интенций. «Теснота стихового ряда», «роман романа», «двупланные амплуа (героев)» - эти метафоры не только передают понятия, но являются «ходом конструктирования» определенного текстового смысла. С другой стороны, научные тексты, богатые полисемантичными терминами с «темной метафорикой», порождают множество различных интерпретаций и могут считаться эквивалентным аналогом художественному произведению.

Вернемся к вопросу о соотношении стиха и прозы в пушкинском тексте, проинтерпретированному в статье Тынянова «О композиции “Евгения Онегина”». Изучение этого вопроса представляет собой структурную задачу тыняновского исследования, уяснение которой должно предшествовать «содержательному» анализу произведения.

Отталкиваясь от принципа динамизма речевого материала, Тынянов вводит понятие «семантического порога», позволяющее в «двух замкнутых конструктивных рядах - стиховом и прозаическом» наблюдать усвоение существенных признаков одного ряда другим.

\footnotetext{
${ }^{1}$ Ср. из ст. Ю.Н. Тынянова «Промежуток»: «Мы забываем, что “Руслан и Людмила" долгое время была не-жанром, ее отказывались считать жанром люди, воспитанные на эпопее, так же как не-жанром был “Евгений Онегин”, с которым трудно было примириться после "Руслана и Людмилы” [Тынянов, 1977, с. 192-193]. См. также из ст. «Литературный факт»: «Попробуем, например, дать определение понятия поэма, т.е. понятия жанра. Все попытки единого статического определения не удаются. Стоит только взглянуть на русскую литературу, чтобы в этом убедиться. Вся революционная суть пушкинской "поэмы" "Руслан и Людмила" была в том, что это была "не-поэма" (то же и с "Кавказским пленником")» [Там же, с. 255].
} 
Проза и поэзия... отличаются не имманентным звучанием, не последовательно проведенным в поэзии принципом установки на звучание, а в прозе - принципом установки на семантику, - а, в существенном, тем, как влияют эти элементы относительно друг друга, как деформирована звуковая сторона прозы ее смысловой стороной (установкой внимания на семантику), как деформировано значение слова стихом... Но при внесении в стих прозаических принципов конструкции (а равно и при внесении в прозу стиховых принципов) несколько меняется соотношение между деформирующим и деформируемым, хотя замкнутые семантические ряды поэзии и прозы и не нарушаются, - так происходит обогащение прозы новым смыслом за счет поэзии и обогащение поэзии новым смыслом за счет прозы [Тынянов, 1977, с. 54-55].

Звучание и значение слова в поэзии и в прозе неравноценны; их различие обусловлено соблюдением конструктивного принципа стихового и прозаического рядов. «Деформация звука ролью значения - конструктивный принцип прозы; деформация значения ролью звучания - конструктивный принцип поэзии. Частичные перемены соотношения этих двух элементов - движущий фактор и прозы и поэзии» [Там же, с. 55] ${ }^{1}$. В связи с этим абсолютизировалась роль конструкиии как построяемой смысл литературного текста. «Смысл поэзии иной по сравнению со смыслом прозы. Такая ошибка возникает легче всего, когда обычный для прозы вид (роман, например), тесно спаянный с конструктивным принципом прозы внедрен в стих. Семантические элементы здесь прежде всего деформированы стихом» [Там же, с. 56]. (В первом варианте предисловия к книге, изданной под названием «Проблема стихотворного языка», Тынянов указал на решающее значение конструкции, строя в определении специфичности стихового слова. Критикуя потебнианство за игнорирование «конструктивного, строевого момента в языке», Тынянов пишет: «За выход из конструкции Потебня платится тем, что у него смешиваются в одно явления разных конструкций - разговорной речи и стиха - и, смешиваясь, не объясняют друг друга, а теснят и затемняют». В зависимости от конструкции «сцепление образов будет у одного и того же поэта одним в одних жанрах, другим - в других, таким - в прозе и иным - в стихе» [Там же, c. 253,254$])$.

Мы процитировали первую главу статьи Тынянова «О композиции “Евгения Онегина"». В ней устанавливаются основополагающие категории, обеспечивающие выявление соотнесенности стиха и прозы, к которым относятся понятия «семантического порога», «деформации», «конструктивного принципа» и «конструкции». Как было сказано выше, термины Тынянова не столько передают понятия, сколько являются инструментом конструктирования смыслового образования текста. В известной мере, терминотворчество для Тынянова было определенной сферой выстраивания смысловых зон в литературном произведении. Так, например, представляя героя (как «крупнейшую семантическую единицу прозаического романа») в качестве «внешнего знака», объединяющего «разнородные динамические элементы» [Там же, с. 56], Тынянов использует понятие деформации для того,

\footnotetext{
${ }^{1}$ В статье «Стиховые формы Некрасова» (1921) Тынянов изложил свои идеи о соотнесенности стиха и прозы, регулируемой с помощью ключа, заданного в некоторой литературной системе: «Стихи от прозы отличаются не столько имманентными признаками, данностью, сколько заданным рядом, ключом. Это создает глубокую разницу между обоими видами; значение слов модифицируется в поэзии звучанием, в прозе же звучание слов модифицируется их значением. Одни и те же слова в прозе значат одно, в поэзии другое». Таким образом, было намечено различение функции и формального элемента, которое в эволюционном отношении может зафиксировать период, когда «...несущественно будет в произведении, написано ли оно стихом или прозой» [Тынянов, 1977, с. 25-26].
} 
чтобы «открыть» смысловое пространство стихового романа, в котором «сам внешний знак приобретает... иной оттенок по сравнению с прозой». Отсюда делается вывод о том, что «...герой стихового романа не есть герой того же романа, переложенного в прозу» [Там же, с. 56].

Понятие стихового романа по-иному освещает как малые структурные единицы пушкинского текста, так и его большие группы. В ходе стихового романа все его элементы оказались деформированы стихом. Особенно это коснулось так называемых «малых единиц» романа в стихах, к которым относятся слова второстепенного значения, выражающие категорию отношений (частицы, например) и выдвигающиеся на степень полноправных слов их метрической ролью в стихе; имена собственные и иностранные слова, подчеркивающие роль стиха с его фоническим деформированием или так называемое «разрушенное слово», не имеющее в прозе самостоятельного значения, являясь лишь эквивалентом слова, в стихе представляется метрически равноправным стиховым словом. Приведем пример на «разрушенное слово» из 34-й строфы третьей главы «Евгения Онегина»:

С запиской этой к О... к тому

К соседу...

И дальше в 37-й строфе той же главы:

Задумавшись, моя душа,

Прелестным пальчиком писала

На отуманенном стекле

Заветный вензель О да Е.

Здесь конкретность образа отступает на задний план перед чисто фоническим явлением, когда стих уподобляет буквы равноправным словам [Тынянов, 1977, с. 73].

В статье о «Евгении Онегине» немало места отведено слову, деформирующемуся в стиховой конструкции: «Слово как элемент значащий отступило перед стиховым словом, было затемнено им» [Там же, с. 75-76]. В изучении пушкинского романа, таким образом, предлагается идти не «сверху» от теоретических предпосылок, но учитывать значимость исследования словесных структур.

Что касается деформации «больших групп» пушкинского текста, здесь несомненный интерес вызывает вопрос о жанровом новаторстве стихового романа, так как в этом случае «предстояло слияние целого прозаического рода со стихом». Стиховая форма «Онегина» была симптомом его новой романной структуры, делая предметом романа сам роман (с этой точки зрения «Евгений Онегин» не роман, а роман романа) [Там же, с. 58]. На более тонком порядке «роман романа»взаимообращенная поэтическая реальность. Сама генитивная форма - колеблющаяся игра слова - создает одновременно эффект сгущения и уплотнения «массы» слова до взрывной возможности разложения его на более «тонкие словесные элементы»: рассыпанная структура слова собирается из значимых и менее значимых поэтических эквивалентов, - весь этот многоуровневый коллаж предстает в открытой необходимости осмыслить пушкинский текст как искусство слова, как мир свободных ассоциаций, стиля и формы; и в то же время генитивная конструкция с точным, но морфологически измененным повтором слова создает ситуацию обращенного на себя слова, слова - «хамелеона», теряющего свою определенность и обрастающего новыми оттенками и красками. В «романе романа» перспектива слова подчинила себе сюжетную перспективу; здесь оказалась 
важна «...не динамика семантических значков, а динамика слова в его поэтическом значении. Не развитие действия, а развитие словесного плана» [Там же, c. 64]. (В связи с этим см. статью Ю.Н. Чумакова «“Евгений Онегин”: Перспектива стиха или перспектива сюжета?», в которой автор, принимая равноправие альтернативы между стихами и сюжетом, все же сходится с Тыняновым в главном его тезисе: «Жанровая ориентация дезориентирует, зато оставляет для самостоятельных читателей пустые строительные площадки, а для доверчивых - миражи. Единораздельность действует и здесь: два различных искусства, искусство слова (стихи) и искусство рассказывания (сюжет, проза), неразрывно связаны, хотя по существу предельно самодостаточны. В результате “Евгений Онегин” являет собой высший образец гармонии, то есть соединение разнородных начал. Поэтому ни перспектива стиха, ни перспектива сюжета не могут подавить друг друга. Выделенные, они движутся в различных сегментах. Однако Тынянов все же был прав: перспектива стиха преломляет сюжетную перспективу, если у сюжета стихотворная природа») [Чумаков, 2000, с. 63-64].

Сверх того, сопряжение прозы с поэзией, бывшее в «Евгении Онегине» структурным принципом жанра, делало ощутимым роль предисловий и примечаний, обнажающих жанровые черты пушкинского романа в стихах: «Предисловия и примечания были для Пушкина ... мотивированным вводом прозаических введений и отступлений, которые, таким образом, оттеняли стих» [Тынянов, 1977, c. 59].

Двумя абзацами выше мы позволили себе «поэтическое» отступление относительно тыняновского образа-термина «роман романа». Дело в том, что термины Тынянова, существующие в контексте его научных работ, аккумулируют в себе силу суггестивной энергии текста и в большей степени провоцируют не к логическому описанию, но к художественно-образной рефлексии. В научных сочинениях Тынянова в непредъявленном виде присутствует суггестия поэтического текста, которая может считаться концептопорождающим механизмом его литературной теории. С этой точки зрения разрабатываемая Тыняновым терминология направлена не столько на теоретическое обоснование историко-литературных фактов, сколько на порождение динамизма восприятия фактов литературы.

Статья Тынянова «О композиции “Евгения Онегина”» первый в онегинистике опыт интерпретирования пушкинского романа в стихах, легитимировавший в качестве смыслообразующего фактора романа его стиховую конструкцию ${ }^{1}$. Явления, имеющие в прозаическом романе конкретную семантическую ощутимость, в романе стиховом приобретали совершенно иной смысл. Например, разговорные интонации диалога, которые в прозе замечались исключительно со стороны значе-

${ }^{1}$ В 1941 году в пушкинском сборнике под редакцией А. Еголина появилась статья Г.О. Винокура «Слово и стих в "Евгении Онегине”». Статья явилась продолжением морфологических штудий 1920-х годов и, в частности, теоретических изысканий Тынянова в области исследования структуры онегинской строфы, а также проблемы автора и жанровой функции метра, пунктирно намеченной Тыняновым в итоговом очерке «Пушкин» (1928). Анализ внутреннего членения онегинской строфы и связи метрической формы как с замыслом «Евгения Онегина», так и с художественными особенностями языка романа, позволил Винокуру выделить различные модификации авторского «я» в романе - «авторрассказчик», «автор - участник событий», «автор - с собственной биографией». Глубокая по прочтению статья Винокура объективировала реальность авторского образа и его роль в смыслопорождении онегинского текста - множественные ипостаси авторского «я» в романе приводят к многочисленным смысловым вариациям в пушкинском романе в стихах. Обращение к поэтике «Евгения Онегина» и аналитическое описание его структур в статье Винокура стало моментом восстановления тыняновской концепции пушкинского романа в общих ее чертах. 
ния, Пушкин употребляет в тех случаях, когда «интонационный налет как бы делает самое повествование некоторою косвенною речью героев»:

Ее находят что-то странной,

Провинциальной и жеманной,

И что-то бледной и худой,

А впрочем очень недурной

или когда мотивировка «автора» дается сквозь призму интонаций героев:

Ей-ей! Не то, чтоб содрогнулась,

Иль стала вдруг бледна, красна...

У ней и бровь не шевельнулась;

Не сжала даже губ она.

Выдвинутость стиха и подчинение остальных элементов художественной структуры пушкинского романа «выдвинутому фактору» определяло специфику авторского присутствия в «Евгении Онегине» на уровне глав, в пределах строфы и в границах одного стихового отрезка. Обратимся ко II строфе первой главы романа, где формы проявления «авторского лица» в наибольшей мере деформированы силою стиха:

\footnotetext{
Друзья Людмилы и Руслана!

С героем моего романа

Без предисловий, сей же час

Позвольте познакомить вас:

Онегин, добрый мой приятель,

Родился на брегах Невы,

Где, может быть, родились вы

Или блистали, мой читатель;

Там некогда гулял и я:

Но вреден север для меня.
}

По количеству переключающихся ассоциаций, связанных с авторским, геройным и читательским (персонажным) мирами, по колебанию интонаций и лексического строя, лежащих в поле автора, эта строфа не имеет себе равных во всем стихотворном корпусе романа. Ровность лексического тона, охватывающая собой весь стиховой отрезок, перебивается интонационными сломами, провоцируемыми авторским присутствием. В первом четверостишии разговорная интонация, принадлежащая автору-персонажу (персонажем его делает принадлежность к «персонажному» читательскому миру), несколько смещена лексическим планом, лежащим в поле автора-творца. Одновременное присутствие автора-творца и автора-персонажа, «выдвинутость» одной из этих авторских масок (в данном случае на первый план выступает маска автора-творца) создает дополнительные ассоциативные ряды, делая слово у Пушкина двупланным.

Конкретность автора-творца во втором четверостишии сдвинута на второй план, вследствие выдвинутости на первый лексических явлений, лежащих в поле автора-персонажа. Ровность интонации в первом и во втором четверостишии нарушена постоянными сменами масок автора: персонажа, творца и повествователя, выдвинутостью одной из них за счет всех остальных. Эти многообразные 
переключения из одного авторского плана в другой провоцировали интонационную игру и внефабульную динамику произведения, оставляя в зонах переключений сюжетно свободные пространства.

«Особенность пушкинского повествования в том, что перед нами не монолог, который ведет автор, а как бы половина диалога, в котором присутствует молчаливый собеседник - читатель» [Цит. по: Виноградов, 1967, с. 87].

Обращение к читателям поэмы «Руслан и Людмила»: «Друзья Людмилы и Руслана», - достаточно было для того, чтобы «вызвать соответствующие ассоциации» и «заставить читателя двигаться в определенном плане» [Тынянов, 1968, c. 131]. «Евгений Онегин» написан так, что создается как бы поле свободного присутствия и участия читателя в написании текста. Читательское сознание конструировало и заполняло сюжетные пустоты, читатель участвовал в создании «образа автора», он волен был отбирать «...только характерное, только так или иначе подсказывавшее черты автора» [Тынянов, 1977, с. 268]. «Молчаливый собеседник - читатель» - это, говоря тыняновским языком, «явление эквивалентности» онегинского текста. Читатели «Руслана и Людмилы» были еще и друзьями героев поэмы, и вслед за этим персонажами создаваемого романа; примеряя и отдавая свои черты автору, они переводили автора-творца в свой «персонажный» план, обнажая прием интонационной игры.

В системе отношений «Евгения Онегина» «идеальный», «авторский» мир в своей колеблющейся изменчивости, пересекает поле более «реального» (им, автором, созданного) мира романа, окрашивая эмпирический романный мир своим «идеальным» сознанием, и получая, в свою очередь, от соприкосновения с ним большую «материальность» и «биографичность». Но «идеальный» автор стоит всегда на пороге им создаваемого; в своей «материальности» он имеет лишь облик, «лицо», «авторское лицо» (предел его литературной конкретности - называние), способное перемещаться в «воображаемых» им мирах, меняя стиль и жанр своего поведения.

И последнее, о чем хотелось бы сказать, в связи с проблемой «автора» в литературном тексте. Выше мы писали об «авторской личности» (термин Тынянова), складывающейся из особенностей лексики и интонационно-фразового рисунка стиха. «Авторское лицо» или «авторская личность» являются отраженными реальностями более сложного внетекстового явления, называемого Тыняновым «литературной личностью». Для того, чтобы литературная личность репрезентовалась в произведении, необходимо, прежде всего, наличие авторской установки на эту личность:

Литературная эволюция связана со сменою установки и сменою «поэта», «лирического героя» - «монологиста»... который затем переходит в поэзию как тематический материал, как «литературная личность» (так, например, Карамзин изменил литературную установку; он сменил «кафедру профессора» на «посох путешественника» и выставил требование «личности»: введение «близких предметов» и «близких идей» [Тынянов, 1968, с. 125].

Вторым подразумеваемым фактом персонификации «литературной личности» является реализуемый в воображаемом поле читателей из стихов «образ поэта», который оказывается далеким от биографической личности автора. Иногда установка на «читателя» требовала изменения формы изложения и, тем самым, создавала разные отношения между конструируемым у читателей «образом поэта» и позицией «авторского лица» в произведении. (В «Архаистах и Пушкине» Тынянов описал эту ситуацию на примере литературной и языковой реформы Карамзина: «Монументальные ораторские жанры сменились маленькими, как бы 
внелитературными, рассчитанными на резонанс салона, жанрами. Литературная эволюция сопровождалась изменением установки на “читателя". “Читатель” Карамзина - это “читательница", “нежная женщина”; автор - Кто пишет так, как го ворит / Кого читают дамы... “Читательница” была оправданием и призмой особой системы эстетизированного, “приятного” литературного языка» [Тынянов, 1968, c. 64]).

В статье «О композици...» Тынянов впервые указал на смысловой статус пропущенных строф в «Евгении Онегине» и обозначил эквивалентную перспективу пушкинского романа в стихах. Все те формальные признаки, которые Тынянов называет эквивалентами поэтического текста, - «...все так или иначе заменяющъие его (текст - E.Б.) внесловесные элементы... частичные пропуски его, затем частичную замену элементами графическими» [Тынянов, 1993, с. 35], - показывали, прежде всего, визуально-графическую моделированность стиха как следствие неисчерпанности его анализа акустическим подходом. Незвуковыми элементами пушкинского романа являлись, в первую очередь, так называемые «пропущенные строфы», обозначенные в тексте нумерацией и отточием. Пользование цифр вместо цельых строф-главок не только динамизировало эквиваленты текста. В этих «динамических значках» сохранялась возможность выстраивания сюжетной схемы романа, которая определялась позицией воспринимающего «субъекта»:

В этих ичифрах даются как бы эквиваленты строф и строк, наполненные любым содержанием; вместо словесных масс - динамический знак, указывающчий на них; вместо определенного семантического веса - неопределенный загадочный семантический иероглиф, под углом зрения которого следующие строфы и строки воспринимаются усложненными, обремененными семантически» [Тынянов, 1977 , c. 60].

Явление эквивалентности пушкинского романа, введенное Тыняновым в статье «О композиции “Евгения Онегина"», в наибольшей мере фиксировало «динамизирующий принцип стиха» и его установку на второстепенные элементы значения в стихотворном тексте. В последующей своей «онегинской» работе, «Проблема стихотворного языка», Тынянов показал смысловую силу эквивалентов текста («...явление эквивалентов означает не понижение, не ослабление, а, напротив, нажим, напряжение нерастраченных динамических элементов» [Тынянов, 1993, c. 37]), обусловленную динамикой слова в его поэтическом значении.

Подведем некоторые итоги наших размышлений.

Тыняновская концепция «литературной эволюции» создавалась на пушкинском материале, а теория о смыслообразующих компонентах литературного текста опиралась, в частности, на роман в стихах «Евгений Онегин». Незакончен ную статью «О композиции “Евгения Онегина"» можно считать «поворотным пунктом» в теоретических построениях Тынянова. Разбираемый в ней онегинский текст представляется Тыняновым в качестве «деформирующего инструмента» для различения стиховых и прозаических признаков художественной речи, что, в свою очередь, является источником важных следствий. Так, например, в пушкинском романе Тыняновым были обнаружены некоторые композиционные приемы, генерирующие восприятие смыслопорождающей природы романной структуры, к которым относятся «сопряжение прозы с поэзией», «пропущенные строфы» или «создание романа романа». В статье о «Евгении Онегине» впервые сформулирована мысль о смыслообразующей функции эквивалентов текста, а также выявлены формы присутствия «авторского лица» в произведении на интонационном уровне. Все перечисленные смыслопорождающие структуры онегинского текста 
определяли новую форму стихового романа, а в нем - смысловой статус слова, деформированного стихом. Таким образом, проблема «смысла стихового слова» (главная тема «Проблемы стихового языка») формировалась в ходе пушкинского романа, а статья «О композиции “Евгения Онегина”» зафиксировала точку наибольшей теоретической устремленности Тынянова в сторону проблем стиховой семантики.

\section{Литература}

Бочаров С.Г. «Форма плана» (Некоторые вопросы поэтики Пушкина) // «Вопросы литературы». 1967. № 12. С. 115-136.

Виноградов В.В. О трудах Ю.Н. Тынянова по истории русской литературы первой половины ХІХ века // «Русская литература». 1967. № 2. С. 81-95.

Винокур Г.О. Слово и стих в «Евгении Онегине» // Пушкин. Сб. статей. М., 1941.

Гинзбург Л.Я. Тынянов-ученый // Воспоминания о Тынянове. Портреты и встречи. М., 1983.

Лотман Ю.М. Роман в стихах Пушкина «Евгений Онегин». Тарту, 1975.

Лотман Ю.М. Художественная структура «Евгения Онегина»// Труды по русской и славянской филологии / Уч. зап. Тартуского ун-та. Вып. 184. Тарту, 1966.

Немзер А.С. В.А. Жуковский в интерпретациях Тынянова // Тыняновский сб.: Четвертые Тыняновские чтения. Рига, 1990.

Тынянов Ю.Н. Пушкин и его современники. М., 1968.

Тынянов Ю.Н. Поэтика. История литературы. Кино. М., 1977.

Тынянов Ю.Н. Литературный факт. М., 1993.

Чумаков Ю.Н. «Евгений Онегин»: интерпретация, поэтика, традиция // Чумаков Ю.Н. Стихотворная поэтика Пушкина. СПб., 1999.

Чумаков Ю.Н. «Евгений Онегин»: Перспектива стиха или перспектива сюжета? // Актуальные проблемы изучения творчества А.С. Пушкина: жанры, сюжеты, мотивы: Материалы Всерос. конф., посвящ. 200-летию со дня рождения А.С. Пушкина (Новосибирск, 21-23 сент. 1999 г.). Новосибирск, 2000.

Чумаков Ю.Н. Состав художественного текста «Евгения Онегина» // Пушкин и его современники. Псков, 1970.

Эйхенбаум Б.М. Вокруг вопроса о формалистах // Хрестоматия по теоретическому литературоведению / Изд. подгот. Чернов И. Тарту, 1976.

Эйхенбаум Б.М. Теория «формального метода» // Эйхенбаум Б.М. О литературе. М., 1987. 